\title{
Biological parameters of Duponchelia fovealis (Lepidoptera: Crambidae) reared in the laboratory on two diets
}

\author{
Maria A.C. ZaWAdneaK, Rodrimar B. GonÇalves, Alex S. Poltronieri, Bráulo Santos, Adélia M. BISChoff, \\ ALINE M. BORBA and IDA C. PIMENTEL
}

Federal University of Paraná, Department of Basic Pathology, 81510-001 Curitiba, Paraná, Brazil; e-mails: mazawa@ufpr.br, rodrimar@engenheiroagronomo.com, alex.poltronieri@yahoo.com.br, bsantos@ufpr.br, adelia_m_b@yahoo.com.br, alinemaryborba@yahoo.com.br, ida@ufpr.br

Key words. Lepidoptera, Crambidae, Duponchelia fovealis, European pepper moth, strawberry, artificial diet, life cycle, development, reproduction, rearing, biological parameters

\begin{abstract}
Duponchelia fovealis Zeller is a polyphagous insect that has been recently reported attacking strawberry plants (Fragaria $x$ ananassa Duchesne). Despite its economic importance there are few studies on this pest because it is difficult to rear it in the laboratory. With a constant supply of insects, studies on alternative methods of pest control can be conducted. This study aimed at developing an artificial diet for rearing $D$. fovealis with biological characteristics similar to those reared on their natural diet. This study was carried out in a climate-controlled room $\left(25^{\circ} \mathrm{C} \pm 2^{\circ} \mathrm{C}, \mathrm{RH} 70 \% \pm 10 \%\right.$, and $14 \mathrm{~L}$ : $\left.10 \mathrm{D}\right)$. The natural diet consisted of 'San Andreas' strawberry leaves (D1), while the artificial diet (D2) was developed in which beans, casein, soy protein, yeast and wheat germ are used as sources of protein. Five instars were identified. $D$. fovealis completed its life cycle in 38 and 40 days when fed D1 and D2, respectively. Survival was highest for the larvae fed the artificial diet. Females fed D1 lay a mean of $300.2 \pm 62.3$ eggs, while those fed D2, $220.3 \pm 41.8$ eggs. The artificial diet is suitable for the continuous rearing of $D$. fovealis in the laboratory.
\end{abstract}

\section{INTRODUCTION}

The European pepper moth Duponchelia fovealis Zeller (Lepidoptera: Crambidae) is a polyphagous insect that attacks plants belonging to 43 botanical families and more than 73 hosts, including ornamental and horticultural plants (Zawadneak et al., 2015). This insect is a pest of strawberry in Portugal, Italy, France, Brazil and Turkey (Bonsignore \& Vacante, 2010; Franco \& Baptista, 2010; Zawadneak et al., 2011, 2016; Efil et al., 2014).

Given the recent history of $D$. fovealis as a nonnative pest and the significant damage it causes (Zawadneak et al., 2016), lack of pest control can have serious economic implications. Thus, biological control may provide an alternative way of managing D. fovealis (Zawadneak et al., 2016). However, in the development of a biological control program of any agricultural pest, the first step is to obtain a good understanding of the basic biology of the target species and how it can be efficiently reared in the laboratory (Sørensen et al., 2012). The rearing of a pest could be optimized by developing an artificial diet (Cohen, 2005; Parra, 2012; Sørensen et al., 2012). The main advantage of using artificial diets instead of natural foods is the continuous supply of laboratory-reared insects of known quality (Sing, 1983).

The objective of this study was to develop an artificial diet for producing $D$. fovealis with biological characteristics similar to those reared on a natural diet.

\section{MATERIAL AND METHODS}

Larvae and adults of $D$. fovealis were collected in a field on an organic farm planted with the strawberry cultivar 'Camino Real' in the municipality of São José dos Pinhais, Paraná, Brazil $\left(25^{\circ} 37^{\prime} \mathrm{S}, 4^{\circ} 04^{\prime} \mathrm{E}\right.$, altitude $\left.900 \mathrm{~m}\right)$. Insects were reared in the laboratory under controlled conditions $\left(25^{\circ} \mathrm{C} \pm 2^{\circ} \mathrm{C}, 70 \% \pm 10 \%\right.$ $\mathrm{RH}$, and $14 \mathrm{~L}: 10 \mathrm{D})$. Larvae were fed the same food substrate as in the field ('Camino Real') to avoid a possible preimaginal conditioning or preference (Liu \& Liu, 2006). Adults were fed a nutritional solution that consisted of $0.5 \mathrm{~g}$ nipagin, $0.5 \mathrm{~g}$ sorbic acid, $30.0 \mathrm{~g}$ sugar, $10 \mathrm{~mL}$ honey, $170 \mathrm{~mL}$ beer and $500 \mathrm{~mL}$ distilled water (Hoffmann-Campo et al., 1985).

The natural diet (D1) consisted of newly expanded 'San Andreas' strawberry leaves from organic crops. After being sanitized with sodium hypochlorite (5\%) and distilled water, the end of the leaf petiole was wrapped in moist cotton wool and placed in an Eppendorf tube $(2.5 \mathrm{~mL})$ to maintain turgor pressure. The leaves were placed in a Petri dish $(9.0 \times 1.5 \mathrm{~cm})$ lined with filter paper and kept at $5^{\circ} \mathrm{C}$.

The diet developed by Greene et al. (1976) (D2) was used as the basis for our study. The artificial diet consisted of seeds of Phaseolus vulgaris L. carioca cultivar (65 g), wheat germ (50 $\mathrm{g})$, textured soy protein $(25 \mathrm{~g})$, casein $(25 \mathrm{~g})$, beer yeast (31 g), bacteriological grade agar (20 g), ascorbic acid ( $3 \mathrm{~g})$, sorbic acid $(1.5 \mathrm{~g})$, methylparaben-nipagin ( $2.5 \mathrm{~g})$, tetracycline $(0.14 \mathrm{~g}), 30 \%$ formaldehyde $(3 \mathrm{~mL})$, Vanderzant vitamin mixture $(8 \mathrm{~mL})$ and 
Table 1. Head capsule widths (mean \pm SE) $(\mathrm{mm})$ and growth ratio (K) of Duponchelia fovealis larvae fed a natural diet consisting of 'San Andreas' strawberry leaves (D1) and the artificial diet (D2) (n $=10$ ) (Means followed by different letters in a row differ based on Student's t-test at $P<0.05)$.

\begin{tabular}{cccccc}
\hline \multirow{3}{*}{ Instar } & \multicolumn{3}{c}{ Head capsules widths (mm) } \\
\cline { 2 - 3 } & \multicolumn{2}{c}{ Natural diet (D1) } & & \multicolumn{2}{c}{ Artificial diet (D2) } \\
\cline { 2 - 3 } \cline { 5 - 6 } & mean \pm SE & $\mathrm{K}$ & & mean \pm SE & $\mathrm{K}$ \\
\hline I & $0.23 \pm 0.01 \mathrm{a}$ & & & $0.21 \pm 0.01 \mathrm{~b}$ & \\
III & $0.33 \pm 0.01 \mathrm{a}$ & 1.44 & & $0.34 \pm 0.01 \mathrm{a}$ & 1.62 \\
IV & $0.51 \pm 0.02 \mathrm{a}$ & 1.53 & & $0.50 \pm 0.02 \mathrm{a}$ & 1.46 \\
V & $0.80 \pm 0.01 \mathrm{a}$ & 1.57 & & $0.77 \pm 0.02 \mathrm{a}$ & 1.55 \\
Mean K & $1.17 \pm 0.02 \mathrm{a}$ & 1.47 & & $1.11 \pm 0.02 \mathrm{~b}$ & 1.44 \\
\hline
\end{tabular}

distilled water $(1,000 \mathrm{~mL})$, to which $\mathrm{V} 8^{\circledR}$ vegetable juice $(50 \mathrm{~mL})$ was added as a phagostimulant. Following preparation, according to Parra (2001), $5 \mathrm{~mL}$ of the diet was placed in sterile Petri dishes ( $6 \mathrm{~cm}$ diameter). After cooling, the Petri dishes were kept at $5^{\circ} \mathrm{C}$.

Newly emerged adults were placed in polypropylene cages $(17 \times 12 \mathrm{~cm})$ that were each topped with a screen, lined with paper towels and kept under controlled conditions $\left(25^{\circ} \mathrm{C} \pm 2^{\circ} \mathrm{C}\right.$, $70 \% \pm 10 \% \mathrm{RH}$, and $14 \mathrm{~L}: 10 \mathrm{D})$. Paper towels were changed daily and eggs were kept in a Petri dish with moistened paper until the larvae hatched. Larvae were transferred to clear plastic boxes $(11 \times 11 \times 3.5 \mathrm{~cm})$ with either diet D1 or D2. Approximately 100 larvae were placed in each box. Leaves (D1) were replaced every two days and the artificial diet (D2) when it began to dry out. Pupae were sexed and kept in Petri dishes. Newly emerged adults were transferred to cages lined with paper towels to collect eggs of the first generation reared on D1 and D2 and for use in experiments.

The greatest width $(\mathrm{mm})$ of the head capsule of ten newly hatched larvae in each treatment were measured. These measurements were made daily, always at the same time, using a stereomicroscope Zeiss ${ }^{\circledR}$ fitted with an ocular micrometer.

For treatments D1 and D2, 210 and 215 eggs were used, respectively. Each egg was kept individually in a Petri dish with moistened paper ( $6 \mathrm{~cm}$ of diameter) and monitored daily. For determining the number of instars and their duration larvae after hatching were kept separately and fed one of the diets (D1 or D2). The prepupal stage was characterized based on morphological (shortening and wrinkling of the body) and behavioral changes (webbing for the construction of the cocoon and inactivity). Pupae up to $24 \mathrm{~h}$ of age were sexed (Genc, 2005), and then placed individually in Petri dishes lined with moistened filter paper until adult emergence. Development time (days) and survival (\%) were determined for each of the stages: egg, larva, prepupa, pupa and egg to adult.

Using the adults that were reared in the laboratory on the two diets, pairs of individuals of the same age were formed $(n=10)$. One pair was placed in each cage, as previously described, in order to monitor reproduction and longevity. Each pair of moths was considered a replicate. Paper towels were changed daily and eggs were counted and kept in a Petri dish lined with moistened paper until the larvae emerged. Fecundity was determined based on the daily and total number of eggs produced per female in each cage, until the death of both male and female.

Larvae from two cages per diet used in the previous experiment were individually placed in clear plastic cups $(80 \mathrm{~mL})$ and fed their corresponding diet until pupation. Twenty-four hours after pupation, pupae were sexed, and weighed $(\mathrm{mg})$ on an analytical balance. The sex ratio, defined as the number of males $(\mathrm{m}) / \mathrm{num}$ ber of females (f): $S R=m / f$, was then calculated.

The experimental design was entirely randomized. The data were tested for normality and homogeneity of variances using the
Table 2. Developmental time (mean \pm SE) (days) and survival (\%) of the different developmental stages: egg, larva, prepupa, and pupa, and egg-adult of Duponchelia fovealis fed a natural diet consisting of 'San Andreas' strawberry leaves (D1) and the artificial diet (D2). Means followed by different letters in a row differ based on Student's t-test at $P<0.05$. Pupa $\mathrm{n}=600$ (D1); $\mathrm{n}=550$ (D2).

\begin{tabular}{lcrrrr}
\hline \multirow{2}{*}{ Life stages } & \multicolumn{2}{c}{ Natural diet (D1) } & & \multicolumn{2}{c}{ Artificial diet (D2) } \\
\cline { 2 - 3 } \cline { 5 - 6 } & Duration & \multicolumn{1}{c}{ Survival } & & Duration & \multicolumn{1}{c}{ Survival } \\
\hline Egg & $5.4 \pm 0.1 \mathrm{a}$ & $87.1 \pm 0.6 \mathrm{~b}$ & & $5.7 \pm 0.1 \mathrm{a}$ & $97.2 \pm 0.3 \mathrm{a}$ \\
$1^{\text {st }}$ instar & $5.3 \pm 0.2 \mathrm{a}$ & $52.5 \pm 0.0 \mathrm{~b}$ & & $3.8 \pm 0.1 \mathrm{~b}$ & $80.4 \pm 1.7 \mathrm{a}$ \\
$2^{\text {nd }}$ instar & $3.9 \pm 0.2 \mathrm{a}$ & $62.3 \pm 0.1 \mathrm{~b}$ & & $4.0 \pm 0.1 \mathrm{a}$ & $98.2 \pm 0.2 \mathrm{a}$ \\
$3^{\text {rd }}$ instar & $3.2 \pm 3.3 \mathrm{a}$ & $80.0 \pm 0.1 \mathrm{~b}$ & & $3.9 \pm 0.1 \mathrm{a}$ & $94.0 \pm 0.3 \mathrm{a}$ \\
$4^{\text {th }}$ instar & $4.1 \pm 0.2 \mathrm{a}$ & $100.0 \pm 0.0 \mathrm{a}$ & & $4.1 \pm 0.1 \mathrm{a}$ & $99.3 \pm 0.1 \mathrm{a}$ \\
$5^{\text {th }}$ instar & $8.7 \pm 0.5 \mathrm{a}$ & $81.3 \pm 0.0 \mathrm{~b}$ & & $7.0 \pm 0.1 \mathrm{~b}$ & $99.9 \pm 0.1 \mathrm{a}$ \\
Prepupa & $2.0 \pm 0.0 \mathrm{a}$ & $94.9 \pm 0.1 \mathrm{a}$ & & $1.8 \pm 0.0 \mathrm{a}$ & $71.0 \pm 0.1 \mathrm{~b}$ \\
Pupa & $7.8 \pm 0.3 \mathrm{a}$ & $94.9 \pm 0.0 \mathrm{~b}$ & $8.2 \pm 0.1 \mathrm{a}$ & $99.9 \pm 0.1 \mathrm{a}$ \\
Egg-Adult & $36.6 \pm 0.7 \mathrm{~b}$ & $17.6 \pm 0.2 \mathrm{~b}$ & $37.7 \pm 0.3 \mathrm{a}$ & $52.4 \pm 0.4 \mathrm{a}$ \\
\hline
\end{tabular}

Kolmogorov and Bartlett tests and the results transformed when necessary. The results were then analyzed using Student's t-test at $P \geq 0.05$. Analyses were carried out using statistical software ASSISTAT, 7.6 beta version (Silva \& Azevedo, 2002).

\section{RESULTS AND DISCUSSION}

D. fovealis underwent five larval instars on both D1 and D2 diets (Table 1). Knowledge of the number of instars is essential for both basic and applied research, such as studies on the biology of this insect, construction of life tables and development of control strategies (McClellan \& Logan, 1994; Logan et al., 1998).

No significant differences were found in head capsule width attributable to diet, except for the $1^{\text {st }}(\mathrm{t}=10.83 ; P \leq 0.001)$ and $5^{\text {th }}$ instars $(\mathrm{t}=6.67 ; P<0.05)$ (Table 1$)$. Regarding growth rate, means followed a geometric progression, as reported by Dyar (1890). The mean growth rates (K) were 1.50 (D1) and 1.52 (D2), which are within the range of variation expected according to Dyar's rule of 1.10 to 1.90 , and similar to the mean ratio of 1.52 reported by Cole (1980) for holometabolous insects. Measurements of head capsule are a good way of determining the growth of insects with homogeneous growth rates (Schmidt et al., 1977).

Insects fed either the strawberry or artificial diet reached the adult stage (Table 2). The mean embryonic development time for eggs laid by insects fed the two diets was similar $(\mathrm{t}=5.65 ; P>$ $0.05)$. First and $5^{\text {th }}$ instar larvae fed D2 developed more quickly $(\mathrm{t}=52.49 ; P<0.001$ and $\mathrm{t}=14.09 ; P<0.001$, respectively) than those fed D1. There were no differences in mean development times of $2^{\text {nd }}$ instar $(\mathrm{t}=0.08 ; P>0.05), 3^{\text {rd }}$ instar $(\mathrm{t}=3.8 ; P>0.05)$ and $4^{\text {th }}$ instar larvae $(\mathrm{t}=0.03 ; P>0.05)$ (Table 2$)$. Larvae reared on D1 took longer to complete their development $(25.9 \pm 0.99$ days) than those reared on $\mathrm{D} 2$ (22.68 \pm 0.61 days). No differences in development time were observed during the prepupal $(\mathrm{t}=1.30$; $P>0.05)$ and pupal stages $(\mathrm{t}=3.56 ; P>0.05)$. The life cycle from egg to adult (Table 2 ) was significantly longer for larvae fed D2 than D1 $(\mathrm{t}=7.04 ; P<0.001)$. D. fovealis completed its life cycle in 36.6 and 37.7 days when fed strawberry leaves (D1) and the artificial diet (D2), respectively.

The mean larval development time recorded for $D$. fovealis (25-28 days) reared on the two diets under controlled laboratory conditions was similar to that reported by Romeijn (1996) and CABI (2016) in the field (28 days). The pupal stage (approximately eight days) was shorter than that reported by Romeijn (1996) (7 to 14 days). D. fovealis adults reared in the laboratory survived approximately 15 days, whereas Romeijn (1996) reported a longevity of approximately 7-14 days and CABI (2016), 14-21 days. This variation indicates that apart from nutrition, environmental conditions may also influence the development of D. fovealis. 
Table 3. Mean ( \pm SE) longevity of females and males, pre-oviposition and oviposition time (days), daily fecundity (mean daily number of eggs), mean total fecundity (mean total number of eggs), mass of pupae (mg) of Duponchelia fovealis fed a natural diet consisting of 'San Andreas' strawberry leaves (D1) and the artificial diet (D2). Means followed by different letters in a row differ based on Student's t-test at $P<0.05$. Pupa $\mathrm{n}=600$ (D1); $\mathrm{n}=550$ (D2)

\begin{tabular}{lcccccc}
\hline & $\begin{array}{c}\text { Natural diet } \\
\text { (D1) }\end{array}$ & $\begin{array}{c}\text { Artificial diet } \\
\text { (D2) }\end{array}$ & $\mathrm{t}$ & $P$ \\
\hline Longevity of females (days) & $16.5 \pm 2.3$ & a & $15.4 \pm 1.5$ & a & 0.07 & 0.80 \\
Longevity of males (days) & $15.5 \pm 2.0$ & a & $15.9 \pm 1.2$ & a & 0.22 & 0.65 \\
Pre-oviposition (days) & $2.6 \pm 0.4$ & b & $3.1 \pm 0.1$ & a & 1.69 & 0.21 \\
Oviposition (days) & $8.2 \pm 0.3$ & a & $8.3 \pm 0.3$ & a & 0.13 & 0.73 \\
Daily fecundity (n) & $33.1 \pm 4.7$ & a & $19.9 \pm 2.9$ & b & 6.38 & 0.03 \\
Total fecundity (n) & $300.2 \pm 62.3$ a & $220.3 \pm 41.9$ a & 1.53 & 0.25 \\
Mass pupa of female (mg) & $22.9 \pm 0.0$ & b & $27.5 \pm 0.3$ & a & 137.88 & 0.0001 \\
Mass pupa of male (mg) & $21.2 \pm 0.0$ & a & $23.0 \pm 0.0$ & a & 1.46 & 0.78 \\
\hline
\end{tabular}

Our results for the developmental stages of $D$. fovealis are similar to those reported in the field and in greenhouses (Huisman \& Koster, 1995; Romeijn, 1996; Bonsignore \& Vacante, 2010; Brambila \& Stocks, 2010; Stocks \& Hodges, 2013; CABI, 2016), indicating the fact that the artificial diet is nutritionally adequate (Panizzi \& Parra, 2012). The use of an artificial diet in the laboratory is desirable, because the nutritional quality of leaves offered as food in the laboratory may vary depending on phenological stage of the natural host, and therefore interfere with the insect's biology (Mihsfeldt \& Parra, 1999).

The percentage survival of the developmental stages of $D$. fovealis were highest on the artificial diet, except in the $4^{\text {th }}$ instar, when there was no difference between diets $(P>0.05)$, and in the prepupal stage, when the percentage survival was higher for individuals fed the natural diet (Table 2). Mortality was highest for $1^{\text {st }}$ instar larvae fed D1. In this developmental stage, larvae measure approximately $1.5 \mathrm{~mm}$ in length (Zawadneak et al., 2015) and are difficult to detect and remove from strawberry leaves due to the hairs. Thus, the lower survival recorded on D1 may not be due to nutritional inadequacy, as indicated by the results on the biology of this pest. Rather, this difference in survival may be due to the handling of larvae during the replacement of food (leaves) in D1. Also, upon entering the prepupal stages, larvae fed D1 use remains of leaves provided as food to construct the cocoon, similar to that observed in nature (Zawadneak, 2011, 2015), while larvae fed D2 do not have access to this substrate and more energy might have to be used to produce the cocoon using only webbing, consequently contributing to the lower viability of prepupae reared on D2.

The longevity of males and females reared on the two diets was similar (Table 3 ), as well as the duration of the preoviposition ( $t$ $=1.69 ; P>0.21)$ and oviposition periods of females reared on $\mathrm{D} 1$ and $\mathrm{D} 2(\mathrm{t}=0.13 ; P=0.73)$. The diet affected daily fecundity, with more eggs laid by females fed D1. The total fecundity of females reared on D1 (300.2 \pm 62.33 eggs) was similar to that of those fed D2 $(220.3 \pm 41.86$ eggs $)(t=1.53 ; P=0.247)$. The total fecundity for D. fovealis females fed D1 (300 eggs) and D2 (220 eggs) are higher than those reported by Huisman \& Koster (1995), Romeijn (1996), Bonsignore \& Vacante (2010), Brambila \& Stocks (2010), Stocks \& Hodges (2013) and CABI (2016) These authors report that females lay approximately 200 eggs during their lifetime but did not specify the food source (host). Since $D$. fovealis eggs measure $0.5 \times 0.7 \mathrm{~mm}$ and are initially translucent, becoming reddish after several days, their detection in the field is difficult (Zawadneak et al., 2015).

From the larvae that hatched from the eggs collected from the two cages for each diet used to determine fecundity, 600 (D1) and 500 pupae (D2) were obtained. Female pupae from the larvae fed the artificial diet were heavier (Table 3 ), while no differences were recorded for males. This is normal in lepidopteran females, since they are heavier than males, feed for longer and need more nutrients for reproduction (Moreau et al., 2006). The mean percentage of deformed pupae was low, $5.4 \%$ in D1 and $7.2 \%$ in D2. Deformities in pupae resulted in abnormal metamorphosis and adults with deformed or swollen wings. The sex ratio (SR) was $1.1: 1$ for D1 and $0.8: 1$ for D2. A sex ratio of approximately $1: 1$ is appropriate for insects (Hamilton, 1967) and according to Parra (2001), in populations of insects with sexual reproduction, one male to one female is supposedly adequate to ensure mating and production of offspring.

Although viability over the whole life cycle (egg to adult) on diets is not above $75 \%$ (Parra, 2012), the diet developed by Greene used in this study to rear $D$. fovealis met the requirements proposed by Sing (1983). The biological parameters of this insect reared on the diet are similar to those recorded on natural diets. The viability and duration of larvae and adults reared on diets should be similar to that observed in nature, and according to Parra (2001), be suitable for more than one species.

This is the first study on biological parameters of $D$. fovealis under controlled conditions. Our results indicate that the artificial diet allows the continuous rearing of $D$. fovealis in the laboratory and that their biological characteristics are similar to those of insects reared on a natural diet. Also, the artificial diet is more effective for the mass rearing of this species, as it is easier to prepare and does not need to be replaced daily, and consequently the insect is subject to less handling. Stable laboratory cultures of this insect are essential for future studies on the development of management strategies for $D$. fovealis.

ACKNOWLEDGEMENTS. We thank the National Council for Scientific and Technological Development (CNPq), the Paraná Research Foundation, PROEXT MEC Sesu for financial support, BIOAgro for providing seedlings from Chile, and A. Solis (Systematic Entomology Laboratory, USDA, Washington, DC, USA) for the identification of $D$. fovealis.

\section{REFERENCES}

Bonsignore C.P. \& VACANTE V. 2010: A new emergency for strawberry? - Protez. Colt. 3: 40-43.

Brambila J. \& Stocks I. 2010: The European Pepper Moth, Duponchelia fovealis Zeller (Lepidoptera: Crambidae), a Mediterranean Pest Moth Discovered in Central Florida. FDACS - Division of Plant Industry. URL: http://www.freshfromflorida.com/content/download/66346/1600726/Pest_Alert_The European_Pepper_Moth_-_Duponchelia_fovealis.pdf (last accessed 4 Jan. 2016).

CABI 2016: Selected Sections for: Duponchelia fovealis (Southern European Marshland Pyralid). Crop Protection Compendium. Invasive Species Compendium (Beta), CABI Internacional, URL: http://www.cabi.org/isc/datasheet/20168 (last accessed 19 Jan. 2016).

CoHEN A.C. 2005: Insect Diets: Science and Technology. Taylor \& Francis, London, $312 \mathrm{pp}$.

COLE J.B. 1980: Growth ratios in holometabolous and hemimetabolous insects. - Ann. Entomol. Soc. Am. 64: 540-544.

DYAR H.G. 1890: The number of molts of lepidopterous larvae. - Psyche 5: 420-422.

EfIL L., ÖZGÜr O. \& EfIL F. 2014: A new pest, Duponchelia fovealis Zeller, on strawberries in Turkey: damage, distribution and parazitoid. - J. Entomol. Zool. Stud. 2: 328-334.

Franco M.C. \& Baptista M.C. 2010: Duponchelia fovealis Zeller - Nova praga em Portugal. - Frutas Legumes Flores 110: 34-35. 
Genc H. 2005: Determination of sex in pupae of Phyciodes phaon (Lepidoptera: Nymphalidae). — Fla Entomol. 88: 536-537.

Greene G.L., Leppla N.C. \& Dickrson W.A. 1976: Velvetbean catterpillar: a rearing procedure and artificial medium. $-J$. Econ. Entomol. 69: 487-488.

Hamilton W.D. 1967: Extraordinary sex ratios. - Science 156: $477-488$.

Hoffmann-Campo C.B.H., Oliveira E.B. \& Moscardi F. 1985: Criação massal da lagarta da soja (Anticarsia gemmatalis). Embrapa/CNPSo, Londrina, 23 pp.

Huisman K.J. \& Koster J.C. 1995: New and interesting microlepidoptera from The Netherlands (Lepidoptera) in the year 1992. - Entomol. Ber. 55: 53-67.

LiU S.S. \& Liu T.X. 2006: Preimaginal conditioning does not affect oviposition preference in the diamondback moth. - Ecol. Entomol. 31: 307-315.

Logan J.A., Bentz B.J., Vandygriff J.C. \& Turner D.L. 1998: General program for determining instar distributions from head capsules widths; example analysis of mountain pine beetle (Coleoptera: Scolytidae) data. - Environ. Entomol. 27: 555-563.

McClellan Q.C. \& Logan J.A. 1994: Instar determination for the gypsy moth (Lepidoptera: Lymantriidae) based on the frequency distribution of head capsule widths. - Environ. Entomol. 23: 248-253.

Minsfeldt L.H. \& ParRa J.R.P. 1999: Biologia de Tuta absoluta (Meyrick, 1917) em dieta artificial. - Sci. Agric. 56: 769-776.

Moreau J., Benrey B. \& Thiery D. 2006: Assessing larval food quality for phytophagous insects: are the facts as simple as they appear? - Funct. Ecol. 20: 592-600.

Panizzi A.R. \& PARRa J.R.P. (eds) 2012: Insect Bioecology and Nutrition for Integrated Pest Management. CRC Press, Boca Raton, FL, 732 pp.

PARRA J.R.P. 2001: Técnicas de criação de insetos para programas de controle biológico. ESALQ/FEALQ, Piracicaba, 134 pp.
PARRA J.R.P. 2012: The evolution of artificial diets and their interactions in science and technology. In Panizzi A.R. \& Parra J.R.P. (eds): Insect Bioecology and Nutrition for Integrated Pest Management. CRC Press, Boca Raton, FL, 732 pp.

RomeIJN G. 1996: Duponchelia fovealis (Zeller): the new hazard. Groenten en Fruit 1996: 12-13.

Schmidt F.H., CAmpBell R.K. \& Trotter S.J. 1977: Errors in determinig instar numbers through head capsules measurements of a Lepidopteran - a laboratory study and critique. - Ann. Entomol. Soc. Am. 70: 750-756.

Silva F.A.S. \& Azevedo C.A.V. 2002: Versão do Programa Computacional Assistat para o sistema operacional Windows. Rev. Bras. Prod. Agroindust. 4: 71-78.

SING P. 1983: A general purpose laboratory diet mixture for rearing insects. - Insect Sci. Appl. 4: 357-362.

Sørensen J.G., Addison M.F. \& Terblanche J.S. 2012: Massrearing of insects for pest management: Challenges, synergies, and advances from evolutionary physiology. - Crop Prot. 38: 87-94.

Stocks S.D. \& Hodges A. 2013: European Pepper Moth or Southern European Marsh Pyralid. University of Florida Dept. of Entomology and Nematology, URL: http://entnemdept.ufl. edu/creatures/veg /leps/european pepper moth.htm (last accessed 7 Jan. 2016).

Zawadneak M.A.C., Gonçalves R.B., Kuhn T.M.A., Dolci E., Rocha C.S, Santos B., Benatto A. \& Vidal H.R. 2011: Novo desafio. - Cultivar HF 8/9: 24-26.

ZAWADNEAK M.A.C., VidAL H.R. \& SANTOS B. 2015: Lagarta-dacoroa, Duponchelia fovealis Zeller. In Vilela E.F. \& Zucchi R.A. (eds): Pragas Introduzidas no Brasil, insetos e ácaros. FEALQ, Piracicaba, pp. 280-298.

Zawadneak M.A.C., Gonçalves R.B., Pimentel I.C., Schuber J.M., Santos B., Poltronieri A.S. \& Solis M.A. 2016: First record of Duponchelia fovealis (Lepidoptera: Crambidae) in South America. — Idesia 34: 91-95.

Received September 20, 2016; revised and accepted May 23, 2017 Published online June 7, 2017 